\title{
Susceptibility of Cultivated and Wild Vitis spp. to Wood Infection by Fungal Trunk Pathogens
}

Renaud Travadon, Department of Plant Pathology, University of California, Davis 95616; Philippe E. Rolshausen, Department of Botany and Plant Sciences, University of California, Riverside 92521; Walter D. Gubler, Department of Plant Pathology, University of California, Davis; Lance Cadle-Davidson, United States Department of Agriculture-Agricultural Research Service (USDA-ARS), Grape Genetics Research Unit, Geneva, NY 14456; and Kendra Baumgartner, USDA-ARS, Crops Pathology and Genetics Research Unit, Davis, CA 95616

\begin{abstract}
Travadon, R., Rolshausen, P. E., Gubler, W. D., Cadle-Davidson, L., and Baumgartner, K. 2013. Susceptibility of cultivated and wild Vitis spp. to wood infection by fungal trunk pathogens. Plant Dis. 97:1529-1536.

Cultivars of European grapevine, Vitis vinifera, show varying levels of susceptibility to Eutypa dieback and Esca, in terms of foliar symptoms. However, little is known regarding cultivar susceptibility of their woody tissues to canker formation. Accordingly, we evaluated the relative susceptibility of $V$. vinifera cultivars ('Cabernet Franc', 'Cabernet Sauvignon', 'Chardonnay', 'Merlot', 'Riesling', 'Petite Syrah', and 'Thompson Seedless') and species or interspecific hybrids of North American Vitis (Vitis hybrid 'Concord', V. arizonica 'b42-26', V. rupestris $\times V$. cinerea 'Ill547-1', and Fennell 6 [V. aestivalis $] \times$ Malaga [V. vinifera] 'DVIT0166') to canker formation by seven trunk pathogens (Neofusicoccum parvum, Lasiodiplodia theobromae, Phaeomoniella chlamydospora, Togninia minima, Phomopsis viticola, Eutypa lata, and an undescribed Eutypa sp.). Susceptibility was based on the length of wood discoloration (LWD) in the woody stems of rooted plants in duplicate greenhouse experiments. Cultivars of $V$. vinifera and

Concord did not vary significantly in susceptibility to $N$. parvum or $L$. theobromae (LWD of 21 to $88 \mathrm{~mm}$ at 14 weeks post inoculation; $P>$ 0.16 ), suggesting that they are similarly susceptible to Botryosphaeria dieback. The table-grape Thompson Seedless was most susceptible to $P$. viticola (mean LWD of $61 \mathrm{~mm}$ at 11 months post inoculation; $P<$ 0.0001). V. vinifera cultivars and Concord showed similar susceptibility to the Esca pathogens, Phaeomoniella chlamydospora and T. minima. Susceptibility to $E$. lata was greatest in $V$. arizonica b42-26 (mean LWD of $96 \mathrm{~mm}$ at 11 months post inoculation; $P<0.03$ ). In fact, all four American Vitis spp. were more susceptible to Eutypa dieback than the $V$. vinifera cultivars. Our findings suggest that no one cultivar is likely to provide resistance to the range of trunk pathogens but that certain cultivars may be promising candidates for commercially relevant host resistance in grape-production systems where the dominant cultivars are very susceptible.
\end{abstract}

Grapevine trunk diseases such as Eutypa dieback, Esca, and Botryosphaeria dieback $(10,22,42)$ impact vineyard production systems (wine, table, raisin, and juice grape cultivars) in all major grape-growing regions of the world. The causal agents are primarily ascomycete fungi, which colonize the permanent woody structure of the vine (trunk, cordons, spurs, and canes) via infection of pruning wounds, causing a chronic infection of the wood. Productivity is reduced over time by death of the spurs, canes, or cordons. For instance, yield losses can reach $94 \%$ in vineyards severely affected by Eutypa dieback (17). The cumulative economic impact of annual yield losses in California vineyards due to Eutypa dieback and Botryosphaeria dieback in wine grapes, for example, accounts for $14 \%$ of the gross producer value (38).

There are no curative fungicides to eradicate wood cankers. Once a grapevine is infected, the only options are to either remove diseased tissues and retrain new cordons or canes from the healthy part of the trunk or replant. Thus, effective control of trunk diseases relies mainly on the prevention of pruning wound infections,

Corresponding author: K. Baumgartner,

E-mail: kbaumgartner@ucdavis.edu

Mention of trade names or commercial products is solely for the purpose of providing specific information and does not imply recommendation or endorsement by the USDA. USDA is an equal opportunity provider and employer.

Accepted for publication 3 July 2013.

http://dx.doi.org/10.1094/PDIS-05-13-0525-RE

This article is in the public domain and not copyrightable. It may be freely reprinted with customary crediting of the source. The American Phytopathological Society, 2013. either by synchronizing pruning with a low-risk period (i.e., low inoculum production [dry weather] and low susceptibility of wounds to infection [end of the dormant season]; 46) or by protective fungicide applications (33). Such control practices are feasible in some grape-production systems, but there are some negative aspects. First, the efficacy of fungicides is reduced when they are washed off pruning wounds by rain. As such, protecting pruning wounds from infection requires repeated applications throughout the dormant season. Second, delaying pruning until the start of dry and warm weather (before bud break) is not feasible in climates with frequent rain in spring, and this practice delays bud break, which can consequently delay harvest.

Cross-sections through arms (cordons) and trunks of vines with dieback reveal a large diversity of wood cankers and discolorations. Grapevine infections by fungal trunk pathogens result consistently in the formation of cankers and discolorations of the wood, but not all trunk pathogens cause diagnostic foliar symptoms. Esca disease, which is caused primarily by Phaeomoniella chlamydospora and Togninia minima (previously known by its asexual stage, Phaeoacremonium aleophilum) (22), is associated with foliar symptoms ranging from a distinct interveinal chlorosis and necrosis of leaves on individual shoots to the total wilting of all leaves on the entire plant (20). Similarly, grapevines affected by Eutypa dieback, caused by Eutypa lata and an undescribed Eutypa sp. recently discovered in northeastern U.S. vineyards (31), frequently show distinct foliar symptoms (dwarfed, distorted, and chlorotic leaves present on stunted shoots) in early spring (10). In contrast, grapevines with Botryosphaeria dieback do not develop diagnostic foliar symptoms, but, instead, develop spur dieback, which is a characteristic of all of the trunk diseases $(20,42)$. Similarly, Phomopsis viticola, the causal agent of Phomopsis cane and leaf spot, is recovered from grapevine wood cankers $(19,28)$; it causes wood cankers (and thus is sometimes referred to as 
'Phomopsis dieback') when inoculated to the woody stems of grapevines, but such infections do not result in diagnostic foliar symptoms $(4,43)$.

Several Vitis vinifera cultivars have been ranked according to their level of susceptibility to Eutypa dieback based on field observations of the foliar symptoms (12). For example, 'Merlot' is considered resistant, whereas 'Cabernet Sauvignon' is considered very susceptible. Cultivar susceptibility to both Eutypa dieback and Esca has been based mainly on field observations, either by examining only the distinct foliar symptoms $(12,14,21)$ or based on a combination of foliar and wood symptoms (40). The problem with some field evaluations of cultivar susceptibility is that the trunk pathogens often occur in mixed infections within a vine (45) and so there may be some uncertainty that the symptoms are due to the effects of a single trunk pathogen. The susceptibility of rootstocks, originating from crosses of North American Vitis spp. such as $V$. berlandieri, V. riparia, and $V$. rupestris, has been examined in controlled conditions (13) or in the field (16), but only with respect to the Esca pathogens. Several studies have investigated $V$. vinifera cultivar susceptibility under controlled conditions (foliar symptoms $[27,47]$ and foliar and wood symptoms [39]). Less is known regarding cultivar susceptibility to the causal agents of Botryosphaeria dieback and Phomopsis dieback, which have more recently been acknowledged as trunk diseases than Eutypa dieback and Esca.

Cultivars that are widely cultivated in the United States, and which represent all vineyard production systems, have not been examined against a comprehensive set of trunk pathogens. In the present study, under controlled conditions, we evaluated the relative susceptibility of seven major commercial $V$. vinifera cultivars and one Vitis hybrid cultivar ('Concord'). We focused on the most aggressive causal species of Botryosphaeria dieback (Neofusicoccum parvum and Lasiodiplodia theobromae), Esca (Phaeomoniella chlamydospora and T. minima), Phomopsis dieback (Phomopsis viticola), and Eutypa dieback (E. lata and Eutypa sp.), the latter species being the most prevalent in vineyards affected by Eutypa dieback in the northeastern United States and southeastern Canada; (31). The susceptibility to wood infection by the two Eutypa spp. was further evaluated among three North American Vitis spp. and interspecific hybrids, which are currently used in breeding programs in the northeastern United States for resistance to the foliar diseases powdery mildew and downy mildew, and in the western United States to Pierce's disease $(9,29,30)$.

\section{Materials and Methods}

Plant material. Experiments were conducted on rooted, 1-yearold dormant cuttings of seven commercial cultivars of $V$. vinifera ('Cabernet Franc' clone 4, Cabernet Sauvignon clone 7, 'Chardonnay' clone 4, Merlot clone 15, 'Riesling' clone 1, 'Petite Syrah' [syn. 'Durif'] clone 3, and 'Thompson Seedless' clone 15) and one interspecific $V$. labrusca interspecific hybrid cultivar (Concord), all of which were provided by commercial nurseries. Included in our study was Thompson Seedless, which is widely planted for table and raisin-grape production in California, and Chardonnay, which is the most widely planted white wine cultivar in the United States.
Representing juice grapes was the interspecific V. labrusca hybrid Concord, a cold-tolerant cultivar widely planted for juice and preserve production in cooler climates of Washington and New York states, Brazil, and Ontario, Canada. The above eight cultivars were challenged with all seven trunk pathogens (Table 1). In addition, two of the pathogens (E. lata M14 and Eutypa sp. NYCc1) were inoculated onto three disease-resistant breeding lines: $V$. hybrid 'Il1547-1' $(V$. rupestris 'B38' $\times V$. cinerea 'B9' resistant to powdery mildew [Erysiphe necator] and downy mildew [Plasmopara viticola]; 9), 'DVIT0166' ( $V$. aestivalis 'Fennell 6' $\times$ V. vinifera 'Malaga,' resistant to powdery mildew; 29), and $V$. arizonica 'b42-26' (resistant to the Pierce's disease pathogen Xylella fastidiosa; 30). For each of these breeding lines, dormant wood was obtained from the only two replicate mother vines maintained at the United States Department of Agriculture-Agricultural Research Service (USDAARS) National Clonal Germplasm Repositories in Davis, CA and Geneva, NY. The reason for studying only Eutypa lata M14 and Eutypa sp. NYCc1 on these ARS accessions is the limited quantity of dormant cuttings that could be obtained for propagation.

Inoculum. Fungal isolates representing seven species of trunk pathogens were used for inoculations. Each isolate was selected based on its high aggressiveness in previous studies (Table 1). For E. lata M14, Eutypa sp. NYCc1, N. parvum UCD646So, and $L$. theobromae UCD197Co, inoculum consisted of mycelial fragments from liquid cultures. To produce the starter culture, 10 2-by2-mm plugs from a 7-day culture on potato dextrose agar (PDA; Difco Laboratories) were inoculated to a 250-ml Erlenmeyer flask containing $100 \mathrm{ml}$ of potato dextrose broth (PDB; Difco Laboratories) and incubated at $25^{\circ} \mathrm{C}$ and $150 \mathrm{rpm}$ (5 days for E. lata and Eutypa sp., 3 days for N. parvum and L. theobromae). A hand-held disperser (IKA-ULTRA-TURRAX T8) equipped with a dispersing element (IKA-S8N-8G) was used to homogenize $40 \mathrm{ml}$ of the PDB culture (1 min, speed 5), and $2 \mathrm{ml}$ of this homogenized starter culture was then inoculated to a $125-\mathrm{ml}$ Erlenmeyer flask containing $40 \mathrm{ml}$ of PDB. After incubation at $25^{\circ} \mathrm{C}$ and $150 \mathrm{rpm}(5$ days for $E$. lata and Eutypa sp., 3 days for N. parvum and L. theobromae), the entire 40-ml liquid culture was homogenized and the concentration of mycelial fragments, which were primarily $<0.5 \mathrm{~mm}$ in length, was estimated with a hemocytometer. The final concentration of inoculum was adjusted with sterile water to $1 \times 10^{6}$ fragments $\mathrm{ml}^{-1}$.

For Phaeomoniella chlamydospora C25, T. minima CBS631.94, and Phomopsis viticola UCD2408Tx, inoculum consisted of conidia. To produce conidial suspensions of Phaeomoniella chlamydospora and T. minima, a starter culture of mycelium was established in $100 \mathrm{ml}$ of PDB, as described above, and incubated at $25^{\circ} \mathrm{C}$ and $150 \mathrm{rpm}$. After 5 days, this starter culture was homogenized, and $100 \mu \mathrm{l}$ of homogenate was spread onto PDA (9$\mathrm{cm}$-diameter plates). Conidia formed on PDA after 12 and 14 days for $T$. minima and $P$. chlamydospora, respectively. To harvest conidia, PDA cultures were flooded with $2 \mathrm{ml}$ of sterile water, a glass rod was used to gently scrape spores from the agar surface, and the suspension was filtered through two layers of cheesecloth to remove fragments of aerial mycelium. The spore concentration was estimated with a hemocytometer and then adjusted with sterile water to $1 \times 10^{6}$ conidia $\mathrm{ml}^{-1}$. To produce conidial suspensions for

Table 1. Trunk pathogens inoculated to potted grapevines in three greenhouse assays

\begin{tabular}{|c|c|c|c|c|c|c|}
\hline Assays $^{x}$ & Pathogen & Isolate & Origin & Host & Inoculum $^{y}$ & Reference \\
\hline \multirow[t]{2}{*}{ Assay 1} & Neofusicoccum parvum & UCD646So & California & Vitis vinifera 'Sauvignon blanc' & Mycelium & 45 \\
\hline & Lasiodiplodia theobromae & UCD197Co & California & V. vinifera 'Perlette' & Mycelium & 45 \\
\hline \multirow[t]{3}{*}{ Assay 2} & Togninia minima & CBS631.94 & Italy & V. vinifera & Conidia & 40 \\
\hline & Phaeomoniella chlamydospora & $\mathrm{C} 25$ & California & $V$. vinifera & Conidia & 34 \\
\hline & Phomopsis viticola & UCD2408Tx & Texas & V. vinifera 'Cabernet Franc' & Conidia $^{\mathrm{z}}$ & 43 \\
\hline \multirow[t]{2}{*}{ Assay 3} & Eutypa sp. & NYCc1 & New York & V. labruscana 'Concord' & Mycelium & 31 \\
\hline & Eutypa lata & M14 & California & $V$. vinifera Merlot & Mycelium & 41 \\
\hline
\end{tabular}

${ }^{\mathrm{x}}$ Greenhouse assays and conditions: Assay 1, Botryosphaeria dieback, 14-week incubation with 8 cultivars; Assay 2, Esca and Phomopsis dieback, 11-month incubation with 8 cultivars; and Assay 3, Eutypa dieback, 11-month incubation with 11 cultivars.

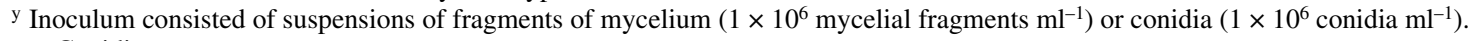

${ }^{\mathrm{z}} \alpha$-Conidia. 
Phomopsis viticola, the isolate was incubated on PDA (9-cmdiameter plate) at room temperature $\left(20 \pm 2^{\circ} \mathrm{C}\right)$. After 6 weeks, a mature pycnidium was transferred to $0.5 \mathrm{ml}$ of sterile water in a 1.5-ml Eppendorf tube and gently crushed with a sterile plastic pestle. The spore suspension was filtered through two layers of cheesecloth, the spore concentration was estimated with a hemocytometer, and the final concentration was adjusted with sterile water to $1 \times 10^{6}$ conidia $\mathrm{ml}^{-1}$.

Inoculation assays. The susceptibility of the grapevine cultivars and accessions to the seven trunk pathogens was assessed by inoculating the woody stems of potted plants in the greenhouse. Three sets of inoculations (assay 1 to assay 3 ) were conducted. In each assay, experiments were repeated a second time over successive years. In each experiment, plants were arranged in a completely randomized design with two blocks corresponding to two greenhouses. For assay 1, Botryosphaeria dieback, there were three treatments: seven $V$. vinifera cultivars and Concord were inoculated with $N$. parvum UCD646So or $L$. theobromae UCD197Co, and noninoculated controls were mock inoculated with sterile PDB. For each treatment, there were 18 replicate plants $(9$ plants per cultivar per block by two blocks by eight cultivars by three treatments by two experiments $=864$ total plants). For assay 2, Esca and Phomopsis dieback, there were four treatments: seven $V$. vinifera cultivars and Concord were inoculated with $P$. chlamydospora C25, Phaeoacremonium aleophilum CBS631.94, or Phomopsis viticola UCD2408Tx, and noninoculated controls were mock inoculated with sterile water. For each treatment, there were 18 replicate plants ( 9 plants per cultivar per block by two blocks by eight cultivars by four treatments by two experiments $=1,152$ total plants). For assay 3, Eutypa dieback, there were three treatments: seven $V$. vinifera cultivars, Concord, $V$. arizonica b42-26, V. rupestris $\times V$. cinerea Ill547-1, and Fennell 6 (V. aestivalis $) \times$ Malaga (V. vinifera) DVIT0166 were inoculated with E. lata M14 or Eutypa sp. NYCc1, and noninoculated controls were mock inoculated with sterile PDB. For each treatment, there were 18 replicate plants ( 9 plants per cultivar per block by two blocks by 11 cultivars by three treatments by two experiments $=1,188$ total plants).

Starting in April 2009 and 2010, dormant cuttings were cut to uniform length (approximately $30 \mathrm{~cm}$ ) containing two to three nodes. Cuttings were surface-sterilized in $1 \%$ sodium hypochlorite (Clorox) for $15 \mathrm{~min}$ and then rinsed in water overnight. Cuttings were then callused in a mixture of perlite and vermiculite (1:1, $\mathrm{vol} / \mathrm{vol}$ ) at $30^{\circ} \mathrm{C}$ and $100 \%$ relative humidity for 3 weeks. Once root and shoot initials emerged from the callus tissue, a power drill was used to wound the woody stem (2-mm width by $3-\mathrm{mm}$ depth) at a point approximately $3 \mathrm{~cm}$ below the uppermost node. Cuttings were inoculated by pipetting $20 \mu \mathrm{l}$ of inoculum into the wound, and then sealing this inoculation site with Vaseline (Unilever) and Parafilm (American National Can). Noninoculated controls were mock inoculated with either $20 \mu \mathrm{l}$ of noncolonized PDB or sterile water, depending on the pathogen (see above). After inoculation, cuttings were submerged in melted paraffin wax (Gulf Wax; Royal Oak Enterprises) within $4 \mathrm{~cm}$ of the roots and potted in UC mix (3) amended with slow-release fertilizer (Osmocote Pro 24-4-9; Scotts). Plants were grown in the greenhouse at the Armstrong Experimental Station at University of California, Davis (natural sunlight photoperiod, $25 \pm 1^{\circ} \mathrm{C}$ [day] and $18 \pm 3^{\circ} \mathrm{C}$ [night]) and were hand watered every 3 days or as required.

Cultivar susceptibility. Plants inoculated with $L$. theobromae and $N$. parvum (assay 1) were examined 14 weeks after inoculation, whereas all other plants (assays 2 and 3) were examined after 11 months. Plants were removed from the soil, roots and shoots were excised, and bark was scraped from the woody stem. Stems were surface sterilized in $1 \%$ sodium hypochlorite solution for 2 min and rinsed with tap water. First, the length of the woody stem was measured. Then, the stem was cut longitudinally and the lesion (i.e., the length of wood discoloration [LWD] extending from the point of inoculation; Fig. 1), was measured with an electronic caliper. In order to confirm that the lesions were caused by the trunk pathogens, four small pieces ( 5 by $2 \mathrm{~mm}$ ) of discolored wood from the margin of each lesion were surface sterilized for $1 \mathrm{~min}$ in $0.6 \%$ sodium hypochlorite solution $(\mathrm{pH} 7.2)$, rinsed in two successive baths of sterile distilled water, and incubated on PDA amended with $0.01 \%$ tetracycline hydrochloride (PDA-tet; Sigma-Aldrich). Plants inoculated with the Esca and Eutypa dieback pathogens were also examined for the presence of diagnostic foliar symptoms.

Statistical analyses. All statistical analyses were conducted in SAS (v. 9.2; SAS Institute). Analyses were conducted separately for each of the three assays. Average cutting lengths (CLs) varied among cultivars. In order to evaluate whether CL variation influenced the LWD, we estimated Pearson correlation coefficients
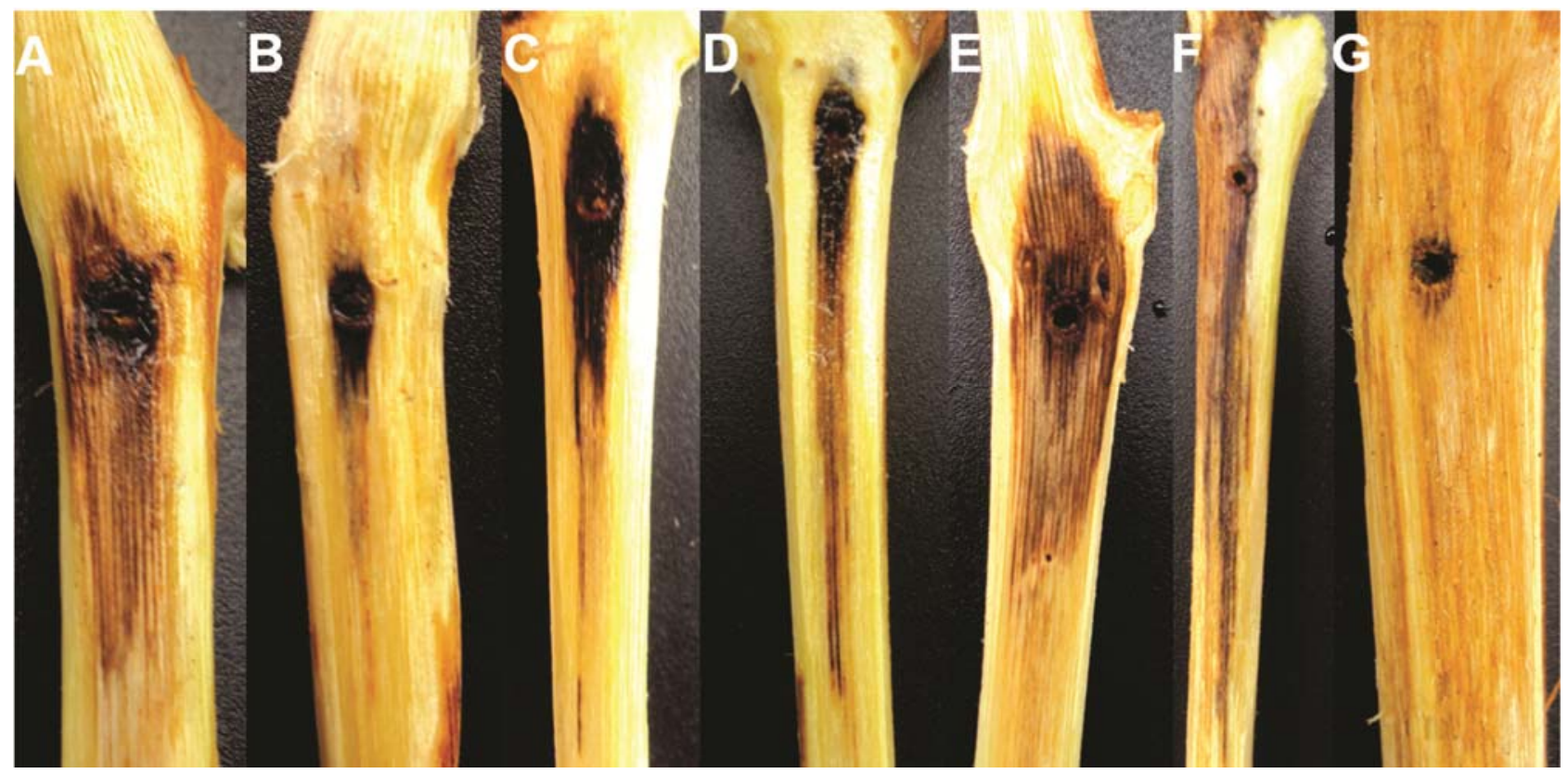

Fig. 1. Representative wood symptoms observed after 11 months of incubation in grapevines inoculated with A and B, Phomopsis viticola ('Cabernet Sauvignon' and 'Chardonnay'); C and D, Phaeomoniella chlamydospora ('Cabernet Franc' and 'Thompson Seedless'); and E and F, Eutypa lata (Cabernet Franc and Vitis arizonica 'b42-26'). G, Noninoculated controls $V$. hybrid Fennell $6(V$. aestivalis $) \times$ Malaga $(V$. vinifera) 'DVIT0166' were wounded in the same way as inoculated plants but were treated with sterile potato dextrose broth instead of inoculum. Inoculation sites on each panel measure $2 \mathrm{~mm}$ in diameter. 
between LWD and CL. A significant and positive correlation would indicate that LWD was influenced by CL. However, there was no such correlation $(\propto=0.05)$ for any treatment-cultivar combination. Hence, LWD was used as the measure of susceptibility. Normality and homogeneity of variances were evaluated using normal probability plots and Levene's test, respectively. When necessary, LWD was transformed (reciprocal square root transformation for assay 1 and log-transformation for assays 2 and 3) to meet parametric assumptions. Analyses of variance (ANOVAs) were used to determine the effect of the treatment, cultivar, and their interaction on LWD. ANOVAs were performed using the MIXED procedure in SAS, with block and experiment considered as random effects. Denominator degrees of freedom were approximated using the Satterthwaite method. Means were calculated using the LSMEANS procedure. $P$ values and confidence limits for mean differences were adjusted for multiple comparisons using the Tukey-Kramer method $(\propto=0.05)$.

Recovery rate was calculated as the percentage of plants from which a pathogen was recovered out of the total number of inoculated plants. To assess the main effect of treatment, cultivar, and their interaction on recovery rate, generalized linear mixed models were performed using the GLIMMIX procedure in SAS, which utilizes the logit link function to accommodate binomial data. The factors block and experiment were considered as random effects and treatment and cultivar as fixed effects. Recovery rates of the noninoculated controls (all of which were zero) were excluded from the analyses. Logistic regression analyses (LOGISTIC procedure in SAS) were used to investigate the relationship between this discrete response (specifically, recovery rate) and LWD as the explanatory variable for each pathogen across cultivars. This latter set of analyses was conducted to evaluate whether recovery of the pathogen from the inoculation site was correlated with a large LWD.

\section{Results}

Assay 1, Botryosphaeria dieback. Fourteen weeks after inoculation, LWD differed significantly among treatments $(P<0.0001$; Table 2). Plants inoculated with $L$. theobromae and $N$. parvum had significantly larger LWD than the noninoculated controls (mean LWD of $3.8 \mathrm{~mm}, n=288$ plants, averaged across cultivars; $P<$ 0.0001 ), illustrating that the wounding of the wood was not the cause of the large LWD of plants inoculated with these two pathogens. Means comparisons between L. theobromae and N. parvum were not significantly different (mean LWDs of 61.2 versus 40.0 $\mathrm{mm}$, respectively, $n=288$ plants per pathogen, averaged across cultivars; $P=0.077$ ), suggesting similar aggressiveness for both

Table 2. $F$ values from mixed linear models of variance for length of wood discoloration (LWD) in grapevine stems after inoculation with the causal agents of Botryosphaeria dieback (Assay 1), Esca and Phomopsis dieback (Assay 2), and Eutypa dieback (Assay 3)

\begin{tabular}{lcc}
\hline Assay, source $^{\mathbf{x}}$ & $\mathbf{d f}^{\mathbf{y}}$ & $\boldsymbol{F}$ value $^{\mathbf{z}}$ \\
\hline Assay 1 & & \\
Treatment & 2 & $446.33^{* * * *}$ \\
Cultivar & 7 & $3.59^{* *}$ \\
Treatment $\times$ cultivar & 14 & 1.28 \\
Assay 2 & & \\
Treatment & 3 & 8.08 \\
Cultivar & 7 & $5.45^{* *}$ \\
Treatment $\times$ cultivar & 21 & 1.25 \\
Assay 3 & & $45.47^{* *}$ \\
Treatment & 2 & $16.28^{* * *}$ \\
Cultivar & 10 & 1.25 \\
Treatment $\times$ cultivar & 20 &
\end{tabular}

${ }^{x}$ Source of variation: Treatment $=$ noninoculated, isolate 1 , isolate 2 , or isolate 3; and Cultivar $=8$ different cultivars for assays 1 and 2 or 11 different cultivars for assay 3 .

${ }^{y}$ Numerator degrees of freedom.

${ }^{\mathrm{z}}$ Asterisks: ${ }^{*},{ }^{* *}$, and $* * *$ indicate significance at $P<0.05,0.01$, and 0.0001 , respectively. pathogens. A significant effect of cultivar on LWD averaged across treatments $(P=0.039$; Table 2$)$ showed differential susceptibility of cultivars. The treatment-cultivar interaction was nonsignificant $(P=0.33$; Table 2$)$, revealing that the wood symptoms among cultivars were relatively consistent between the two pathogens. Nonetheless, means comparisons following ANOVA showed no significant differences in mean LWD among cultivars. Albeit nonsignificant, Thompson Seedless was the most susceptible cultivar to both pathogens. For plants inoculated with $L$. theobromae, mean LWD was $32 \mathrm{~mm}$ for Cabernet Sauvignon (most resistant) and 88 $\mathrm{mm}$ for Thompson Seedless (most susceptible) (Fig. 2A). For plants inoculated with $N$. parvum, mean LWD was $21.4 \mathrm{~mm}$ for Concord (most resistant) and $65 \mathrm{~mm}$ for Thompson Seedless (most susceptible) (Fig. 2B). Means comparisons showed that there were no significant differences in LWD among cultivars for the noninoculated controls $(P>0.85)$, which had mean LWDs of 3.2 to 4.6 $\mathrm{mm}$ for Cabernet Franc and Thompson Seedless, respectively.

There were no differences in recovery rates due to the effects of pathogen $(P=0.16)$, cultivar $(P=0.14)$, or their interaction $(P=$ $0.90)$. Also, recovery of $L$. theobromae and $N$. parvum was not related to LWD ( $P$ values of 0.25 and 0.10 , respectively; Table 3 ), which may be due, in part, to the relatively high recovery rates of both pathogens from inoculated plants $(\geq 80 \%$, Table 3$)$.
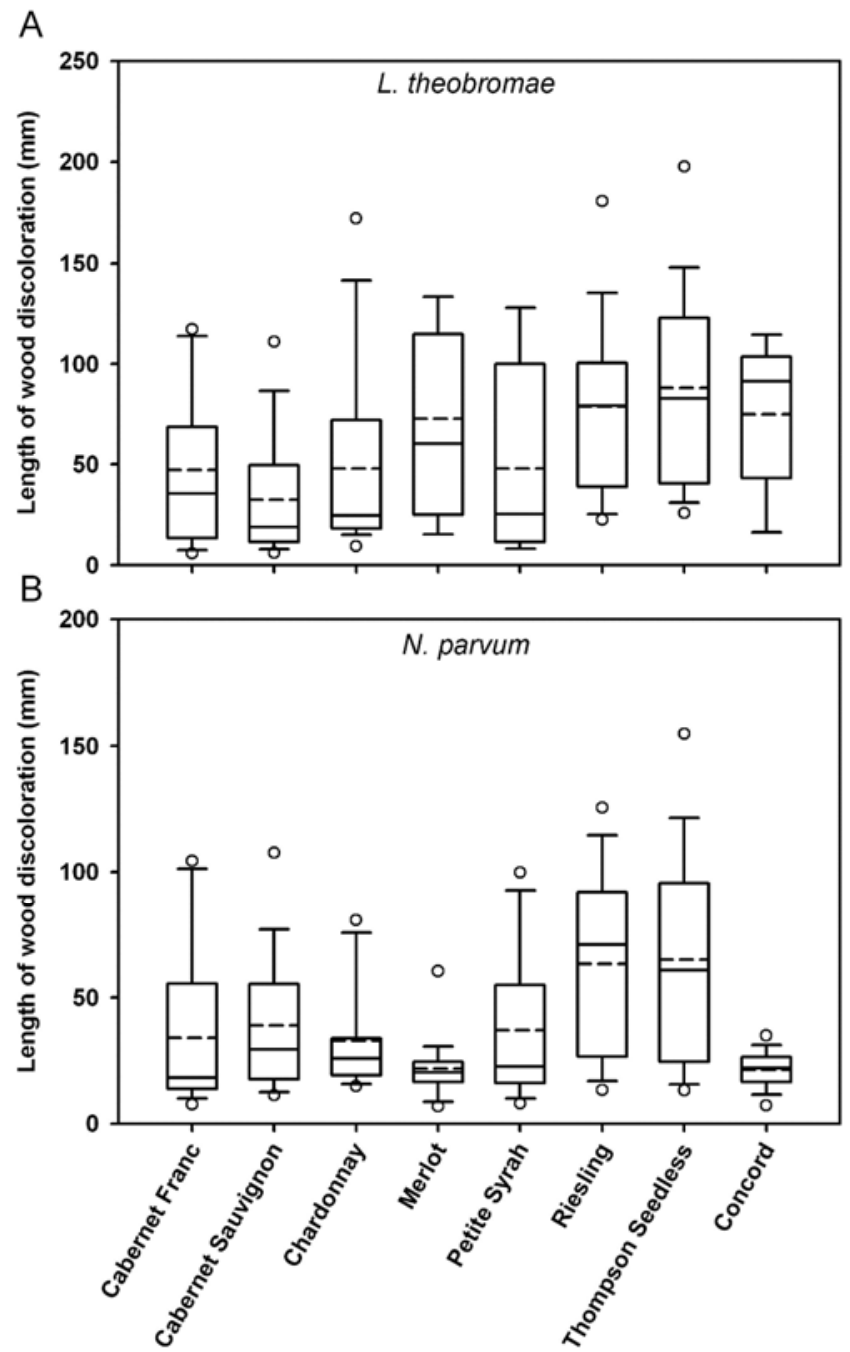

Fig. 2. Assay 1. Grapevine cultivar susceptibility to Botryosphaeria dieback. Box plots illustrating the distribution of length of wood discoloration (LWD) measured in eight cultivars at 4 months after inoculations with A, Lasiodiplodia theobromae or B, Neofusicoccum parvum. Solid and broken lines within the box correspond to the median and mean, respectively. Top and bottom lines of the box correspond to the 25 th and 75 th percentiles of the data, respectively. Error bars represent the 10th and 90th percentiles, and circles represent the 5th and 95th percentiles. 
Assay 2, Esca and Phomopsis dieback. There were significant differences among cultivars inoculated with $P$. viticola $(P<$ 0.0001). Means comparisons showed that Thompson Seedless developed significantly longer LWD $(61.3 \mathrm{~mm})$ than all other cultivars $(P<0.0001$; Fig. $3 C)$. Mean LWD did not differ significantly among treatments $(P=0.062$; Table 2$)$. LWD of the noninoculated controls $($ mean $=4.2 \mathrm{~mm}$ ), albeit restricted, was not significantly different from that of plants inoculated with $P$. viticola (mean LWD of $22.4 \mathrm{~mm}, n=288$ plants, averaged across cultivars; $P=0.14$ ), $T$. minima (mean LWD of $19.9 \mathrm{~mm}, n=288$ plants, averaged across cultivars; $P=0.13$ ), or Phaeomoniella chlamydospora (mean LWD of $40.3 \mathrm{~mm}, n=288$ plants, averaged across cultivars; $P=0.05$ ). The main effect of cultivar on mean LWD across treatments was significant $(P=0.0003$; Table 2$)$, indicating an overall differential susceptibility of cultivars. However, means comparisons showed no significant differences among cultivars inoculated with the causal agents of Esca. Among plants inoculated with T. minima, there was no significant effect of cultivar on LWD $(P=0.11$; Fig. $3 \mathrm{~A})$, with LWD of $14 \mathrm{~mm}$ for Cabernet Sauvignon (most resistant) to $37.9 \mathrm{~mm}$ for Thompson Seedless (most susceptible). Similarly, there was no significant effect of cultivar on LWD for plants inoculated with $P$. chlamydospora $(P=0.39$; Fig. 3B), with LWD of $27.6 \mathrm{~mm}$ for Cabernet Sauvignon (most resistant) to $50 \mathrm{~mm}$ for Concord (most susceptible). In spite of the fact that all plants inoculated with the Esca pathogens developed wood symptoms (Fig. 1), no foliar symptoms were observed in either replication of the experiment.

For both Esca pathogens and $P$. viticola, there was a significant relationship between recovery rate and large LWD ( $P$ values of $P<$ 0.0001 to $P=0.001$; Table 3 ). Proc GLIMMIX showed no differences in recovery rates due to the effects of pathogen $(P=0.95)$, cultivar $(P=0.62)$, or their interaction $(P=0.97)$ (data not shown).

Assay 3, Eutypa dieback. Eleven months after inoculation, in experiment 1, no plants showed foliar symptoms of Eutypa dieback; whereas, in experiment 2 (second year), a total of eight plants (one each of Cabernet Sauvignon, Chardonnay, and Petite Syrah inoculated with Eutypa sp. NYCc1; and one each of Cabernet Sauvignon, Chardonnay, Riesling, and two of Petite Syrah inoculated with E. lata M14) had stunted shoots with small, chlorotic, and tattered leaves. However, given the small number of plants with foliar symptoms, no statistical analyses were performed.

Table 3. Variation in recovery rates among seven trunk pathogens inoculated to Vitis vinifera cultivars and North American Vitis spp. or interspecific hybrids in three greenhouse assays ${ }^{\mathrm{w}}$

\begin{tabular}{lcc}
\hline Assay, pathogen & $\begin{array}{c}\text { Recovery } \\
\text { rate }^{\mathbf{y}}\end{array}$ & $\begin{array}{c}\text { Regression } \\
\text { slope } \boldsymbol{\beta}^{\mathbf{z}}\end{array}$ \\
\hline $\begin{array}{l}\text { Assay 1 } \\
\text { Lasiodiplodia theobromae UCD197Co }\end{array}$ & $0.89 \mathrm{a}$ & $0.68(0.2486)$ \\
$\quad \begin{array}{l}\text { Neofusicoccum parvum UCD646So } \\
\text { Assay 2 }\end{array}$ & $0.80 \mathrm{a}$ & $0.89(0.0979)$ \\
$\quad$ Togninia minima CBS631.94 & $0.55 \mathrm{a}$ & $2.06(0.0008)$ \\
Phaeomoniella chlamydospora C25 & $0.58 \mathrm{a}$ & $2.26(<0.0001)$ \\
Phomopsis viticola UCD2408Tx & $0.56 \mathrm{a}$ & $1.76(0.0009)$ \\
Assay 3 & & \\
$\quad$ Eutypa sp. NYCc1 & $0.25 \mathrm{a}$ & $0.02(0.0105)$ \\
Eutypa lata M14 & $0.29 \mathrm{a}$ & $0.02(0.0019)$ \\
\hline
\end{tabular}

${ }^{w}$ Slopes $\beta$ of logistic regressions reflect the relationship between the discrete response (recovery rate) and the explanatory variable (length of wood discoloration [LWD]). For every one unit increase in LWD, the logodds for positive recovery of the pathogen increases by $\beta$.

${ }^{x}$ Greenhouse assays: Assay 1, Botryosphaeria dieback; Assay 2, Esca and Phomopsis dieback; and Assay 3, Eutypa dieback

${ }^{y}$ Recovery rate was calculated as the percentage of plants from which the pathogen was recovered out of the total inoculated, averaged across cultivars. For each assay, values followed by the same letter are not significantly different at $P \leq 0.05$, Tukey's test.

${ }^{\mathrm{z}}$ Slope of logistic regression between recovery rate and LWD (averaged across cultivars). $P$ values associated with the null hypothesis of $\beta=0$ are given in parentheses.
Wood discolorations developed from the inoculation sites in the woody stems of all cultivars inoculated with the causal agents of Eutypa dieback (Fig. 1E and F). LWD differed significantly among treatments $(P=0.0045$; Table 2$)$, with similar mean LWD between Eutypa sp. and E. lata (mean LWDs of 25.1 versus $35.3 \mathrm{~mm}$, re-
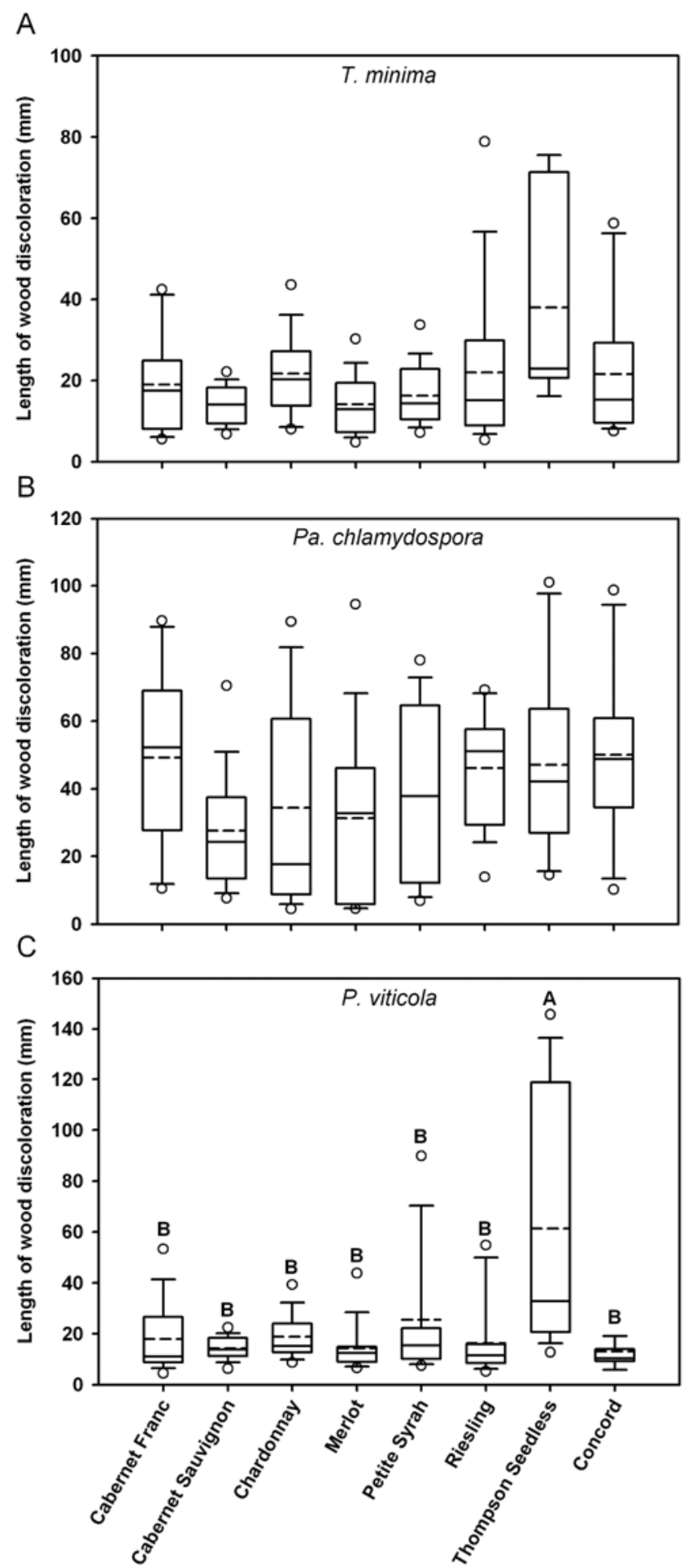

Fig. 3. Assay 2. Grapevine cultivar susceptibility to Esca and Phomopsis dieback. Box plots illustrating the distribution of length of wood discoloration (LWD) measured in eight cultivars at 11 months after inoculations with A, Togninia minima; B, Phaeomoniella chlamydospora; or C, Phomopsis viticola. Solid and broken lines within the box correspond to the median and mean, respectively. Top and bottom lines of the box correspond to the 25th and 75th percentiles of the data, respectively. Error bars represent the 10th and 90th percentiles, and circles represent the 5th and 95th percentiles. Mean LWDs of cultivars with different letters are significantly different at $P \leq 0.05$, Tukey's test. 
spectively, $n=396$ plants per pathogen, averaged across cultivars; $P=0.32)$. Mean LWD of the noninoculated controls $(4.7 \mathrm{~mm}, n=$ 396 plants, averaged across cultivars; Fig. 1G) was significantly smaller than those of the inoculated plants $(P<0.009)$. The effect of cultivar on LWD was highly significant $(P<0.0001$; Table 2$)$, which may be due, in part, to the inclusion of different Vitis spp. (technically not cultivars but germplasm accessions) in this assay. $V$. arizonica b42-26 had the largest LWD for both Eutypa sp. and E. lata (mean LWDs of 83.7 versus $96.5 \mathrm{~mm}$, respectively, $n=36$ plants; Fig. 4A and B). Among plants inoculated with Eutypa sp., $V$. arizonica b42-26 was significantly more susceptible than all cultivars (mean LWDs of $15.6 \mathrm{~mm}$ for Petite Syrah [most resistant] to $24.2 \mathrm{~mm}$ for Riesling, $n=36$ plants per cultivar; $P<0.023$ ), except for Thompson Seedless (LWD $=31.3 \mathrm{~mm}, n=36$ plants; $P$ $=0.07$ ). Among plants inoculated with E. lata, V. arizonica b42-26 was significantly more susceptible than all cultivars (mean LWDs of $20.2 \mathrm{~mm}$ for Cabernet Franc [most resistant] to $36.9 \mathrm{~mm}$ for Riesling, $n=36$ plants per cultivar; $P<0.033$ ), except for Thompson Seedless and Fennell 6 (V. aestivalis) $\times$ Malaga ( $V$. vinifera) DVIT0166 (mean LWDs of 50.2 and $38.2 \mathrm{~mm}$, respectively, $n=36$ plants per cultivar; $P>0.05$ ). Interestingly, there were significant differences in LWD among cultivars for the noninoculated controls $(P=0.028)$. Means comparisons revealed that LWD of noninocu-

A

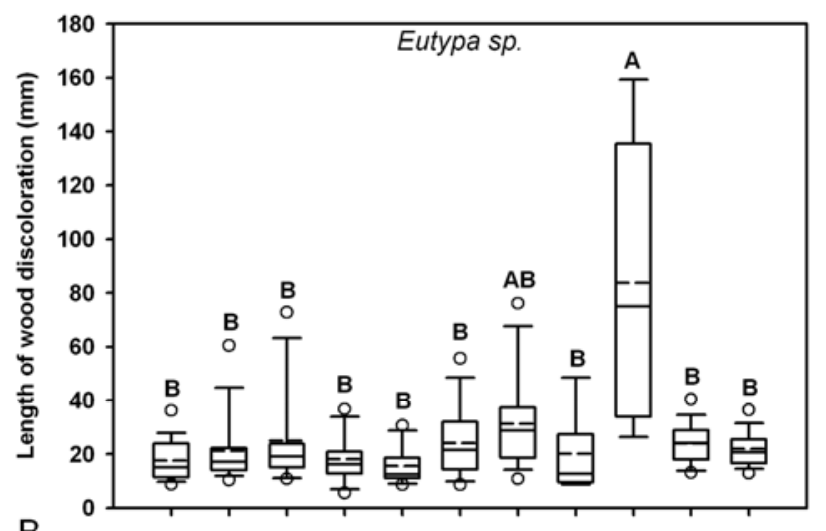

B

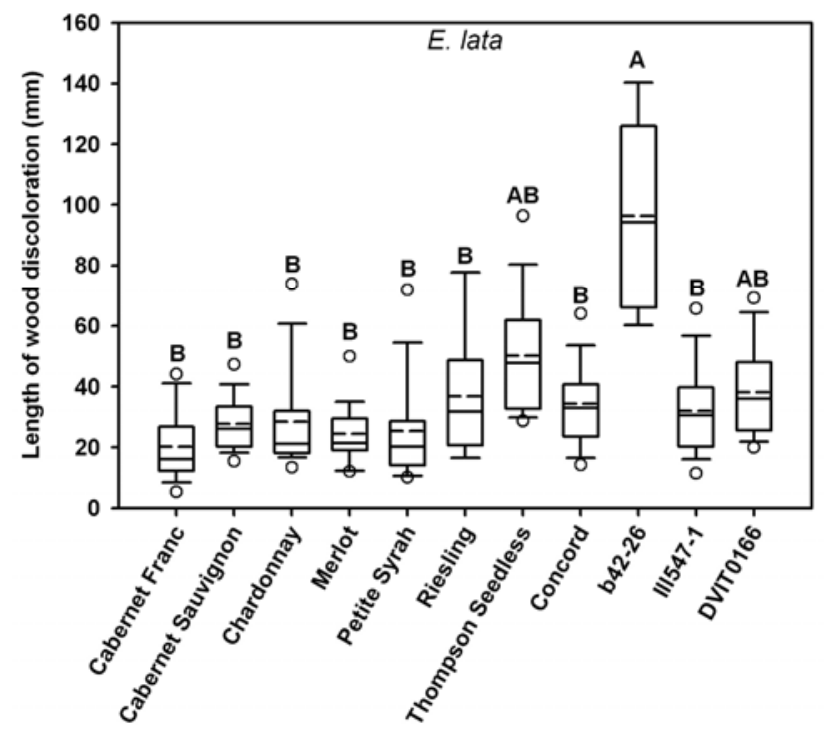

Fig. 4. Assay 3. Grapevine susceptibility to Eutypa dieback. Box plots illustrating the distribution of length of wood discoloration (LWD) measured in 11 cultivars at 11 months after inoculations with A, Eutypa sp. or B, Eutypa lata. Solid and broken lines within the box correspond to the median and mean, respectively. Top and bottom lines of the box correspond to the 25th and 75th percentiles of the data, respectively. Error bars represent the 10th and 90th percentiles, and circles represent the 5th and 95th percentiles. Mean LWDs of cultivars with different letters are significantly different at $P \leq 0.05$, Tukey's test. lated $V$. arizonica $\mathrm{b} 42-26(\mathrm{LWD}=8.9 \mathrm{~mm})$ was significantly larger than those of Cabernet Franc, V. labruscana Concord, V. rupestris $\times V$. cinerea Ill547-1, and Fennell $6(V$. aestivalis $) \times$ Malaga $(V$. vinifera) DVIT0166 (mean LWDs of 3.8, 3.8, 3.9, and $3.9 \mathrm{~mm}$, respectively; $P<0.026$ ).

There were no differences in recovery rates due to the effects of pathogen $(P=0.42)$, cultivar $(P=0.30)$, or their interaction $(P=$ 0.78) (data not shown). For both E. lata and Eutypa sp., there was a significant relationship between recovery rate and large LWD $(P$ values of 0.01 to 0.002 ; Table 3 ).

\section{Discussion}

Among eight cultivars of grapevine, our controlled inoculations conducted in duplicate greenhouse experiments revealed differential levels of grapevine resistance to wood symptoms caused by Phomopsis viticola, E. lata, and Eutypa sp. Thompson Seedless was the most susceptible to $P$. viticola, and this finding is consistent with the high incidence of Phomopsis dieback in this tablegrape cultivar in California (45). It has always been puzzling to see a high incidence of this disease in Thompson Seedless vineyards, especially because they are located primarily in the southern San Joaquin Valley, which has a very low annual rainfall (less than 280 $\mathrm{mm}$ ). Because the dispersal of $P$. viticola is thought to be primarily by rain splash of its conidia (24), it may be that the relatively high susceptibility to $P$. viticola brings about a high disease incidence in spite of few rain events. Thompson Seedless, the only Mediterranean table grape cultivar examined in this study (2), originating from Turkey, was also more susceptible to E. lata and Eutypa sp. than any other $V$. vinifera cultivar. Past field inoculations of mature plants with E. lata have shown that Merlot (along with 'Gamay', 'Grenache', and 'Sémillon') developed less severe wood symptoms and, thus, was more resistant to Eutypa dieback than Cabernet Sauvignon (along with 'Syrah', 'Pinot noir', and Riesling; 39). In our study, however, wood symptoms caused by $E$. lata were not significantly different between Merlot and Cabernet Sauvignon, although this may be due to the fact that the much higher LWD of Thompson Seedless obscured more subtle statistical differences between other cultivars. It may also be due, in part, to the fact that we inoculated 1-year-old woody stems and Sosnowski et al. (39) inoculated much more mature vines. Relative differences in Eutypa susceptibility among Merlot and Cabernet Sauvignon may be more pronounced as the wood ages and the lignin content and cell-wall composition changes. Indeed, Merlot has been shown to have higher lignin content than Cabernet Sauvignon (32).

For the grape diseases powdery mildew, downy mildew, and Pierce's disease, North American Vitis spp. are known to have greater resistance than $V$. vinifera cultivars $(8,9)$, which is due, in part, to the common geographic origins of these diseases in America $(5,25,35)$. Therefore, we hypothesized that germplasm accessions with resistance to these other grape diseases may have resistance to trunk diseases. However, V. arizonica b42-26, which is resistant to the xylem-limited bacterium $X$. fastidiosa (30), was the most susceptible to E. lata and Eutypa sp. Additionally, the North American hybrid Fennell 6 ( $V$. aestivalis) $\times$ Malaga ( $V$. vinifera) DVIT0166, which is resistant to the obligate biotrophic fungus $E$. necator (9), showed higher susceptibility to E. lata than most $V$. vinifera cultivars. Because the center of origin for $E$. lata is thought to be Europe (41), co-evolution of the pathogen and $V$. vinifera may have enriched cultivars of this species for increased resistance to $E$. lata relative to the North American $V$. arizonica and $V$. aestivalis. Alternatively, the mechanisms of resistance to a biotrophic xylem-limited bacterium or to a biotrophic foliar fungus may be in opposition to those required to resist fungal colonization of wood. V. arizonica b42-26 and Fennell 6 (V. aestivalis) $\times$ Malaga ( $V$. vinifera) DVIT0166 are parents of mapping populations crossed to $V$. vinifera. With the $V$. vinifera parent likely being more resistant, further characterization of the segregation of resistance in these populations could result in the genetic mapping and characterization of genes associated with resistance to trunk diseases. 
All cultivars or accessions developed wood lesions after inoculation with the causal agents of Botryosphaeria dieback, Esca, Phomopsis dieback, and Eutypa dieback, indicating that there is no evidence of qualitative resistance to these ascomycete fungi. Our deliberate examination of resistance of woody tissue to discoloration and canker formation was necessary to compare all trunk diseases in a set of greenhouse assays. This is because Botryosphaeria dieback and Phomopsis dieback are not associated with diagnostic foliar symptoms $(4,20,42)$, and foliar symptoms of Esca have very rarely been reproduced consistently under controlled conditions (22). That said, plant defense mechanisms against wood symptoms and foliar symptoms may differ (at least for Eutypa dieback and Esca) (39), because the foliar symptoms are thought to result from the translocation of phytotoxic compounds from infected wood to the shoots and leaves (26), whereas the wood-canker symptoms are thought to result primarily from enzymatic decomposition of the wood (32).

Defense mechanisms of woody tissue against decay fungi are thought to involve chemical barriers, which can impede fungal growth $(36,37)$. Several studies have investigated the nature of chemicals present in the reaction zone of grapevine wood infected with trunk pathogens. For example, differential cultivar susceptibility to pruning-wound infections by E. lata is thought to depend on the rates of suberin and lignin deposition involved in the "healing" of the wounds (23). Also, comparisons of total phenolic concentrations of woody tissues degraded by the Esca pathogens indicate that these compounds may restrict fungal colonization of the wood (1). Phenolic acids and stilbenoids, in particular, were found to have fungistatic activity against fungi associated with Botryosphaeria dieback and Eutypa dieback when evaluated in vivo; however, their role in fungal defense in planta is not clear (18). In our study, the relatively uniform LWDs among eight cultivars challenged with the Esca pathogens was surprising, given that differences in the severity of wood symptoms have previously been reported for other $V$. vinifera cultivars 'Italia' (susceptible) and 'Matilde' (resistant) (40), which were also found to differ in phenolic concentrations (7). Our results may reflect the higher similarity among the eight $V$. vinifera cultivars examined in the quality, composition, and distribution of phenolics synthesized in response to wood infections.

The outcomes of fungal infection may also depend on physical barriers inherent to wood anatomy (37) or the capacity for the host to bring about anatomical changes. The distribution and content of parenchyma cells in the sapwood (i.e., living wood where sap flows) has been shown to constitute the main factor influencing the extent of wood decay due to wood-colonizing fungi (basidiomycetes and ascomycetes) in several tree species (11). In our study, no significant interaction effect between pathogen and cultivar on the extent of wood discolorations was detected in any of the three experiments conducted. This supports the hypothesis that wood reaction to wounding and infection are not pathogen-specific but, rather, depend on wood anatomy (11). The greatest differences in wood symptoms after inoculations with the Eutypa spp. were observed between all $V$. vinifera cultivars and $V$. arizonica, the latter being the most susceptible. Interestingly, the resistance of $V$. arizonica to $X$. fastidiosa is thought to be due, in part, to its inability to produce xylem occlusions (tyloses, gums, and fibrillar networks), compared with $X$. fastidiosa-susceptible cultivars of $V$. vinifera, which do undergo such anatomical changes in response to infection by the bacterium (15). It is possible that the low levels of xylem occlusions in $V$. arizonica relative to $V$. vinifera explain the high susceptibility of $V$. arizonica to the Eutypa spp. in our study. Identifying anatomical or biochemical markers of resistance in plant cell walls would help provide reliable markers of resistance.

In our study, there was a trend of greater susceptibility of Thompson Seedless compared with the wine grape Chardonnay to L. theobromae and N. parvum. This is in contrast to a past study, in which Thompson Seedless was found to be more resistant than Chardonnay to L. theobromae (44). Several hypotheses could explain these discrepancies. First, differences may arise from in- travarietal variation among different clones of the same cultivar. Second, isolates from distinct geographic origins (i.e., Mexico versus United States) may differ in their aggressiveness on different hosts. Finally, different inoculation methods may produce different results in LWDs. In our study, we attempted to establish more uniform wound sizes and levels of inoculum among replicate plants by inoculating with mycelial fragments in suspensions. This modification reduced the wound to $2 \mathrm{~mm}$ in diameter instead of the standard 4- to 5-mm-diameter wound required for inoculum in the form of an agar plug (39). Also, the use of a homogenized liquid culture allowed us to quantify the inoculum (i.e., $1 \times 10^{6}$ mycelial fragments $\mathrm{ml}^{-1}$ ), which is not possible for an agar plug colonized by mycelium. In spite of our efforts, there was a fair amount of variation in LWD within some treatments. Grape wood xylem displays asymmetrical features, with larger vessels present in dorsal or ventral sections of the stems relative to smaller, lateral vessels, which are aligned longitudinally with buds and tendrils (6). Therefore, it is possible that the position and depth of the wound, which is difficult to judge precisely from plant to plant when using a power drill, influenced the subsequent colonization of the vessels by the inoculum. Thus, a wound that happened to span larger vessels may have promoted faster colonization of the wood, resulting in larger LWD. Further work is necessary to disentangle the effects of intravarietal phenotypic variation, pathogen-cultivar adaptation, and inoculation methods on differential wood responses to fungal infection.

\section{Acknowledgments}

This research was funded by grant number 2008-51100-19334 to K. Baumgartner, P. Rolshausen, and W. D. Gubler from the USDA, National Institute of Food and Agriculture. We thank A. Walker (University of California, Davis) for providing Vitis cuttings and access to grapevine propagation material; J. Groom, M. Cownan, O. Youngers, and P. Fujiyoshi for technical assistance; and B. Mackey (USDA-ARS, Albany, CA) for his assistance with statistical analyses.

\section{Literature Cited}

1. Agrelli, D., Amalfitano, C., Conte, P., and Mugnai, L. 2009. Chemical and spectroscopic characteristics of the wood of Vitis vinifera $\mathrm{cv}$. Sangiovese affected by Esca disease. J. Agric. Food Chem. 57:11469-11475.

2. Aradhya, M. K., Dangl, G. S., Prins, B. H., Boursiquot, J. M., Walker, M. A., Meredith, C. P., and Simon, C. J. 2003. Genetic structure and differentiation in cultivated grape, Vitis vinifera L. Genet. Res. 81:179-192.

3. Baker, K. F. 1957. The UC System for Producing Healthy Container-Grown Plants. University of California Press, Berkeley.

4. Baumgartner, K., Fujiyoshi, P. T., Travadon, R., Castlebury, L. A., Wilcox, W. F., and Rolshausen, P. E. 2013. Characterization of species of Diaporthe from wood cankers of grape in eastern North American vineyards. Plant Dis. 97:912-920.

5. Brewer, M. T., and Milgroom, M. G. 2010. Phylogeography and population structure of the grape powdery mildew fungus, Erysiphe necator, from diverse Vitis species. BMC Evol. Biol. 10:268-280.

6. Brodersen, C. R., Lee, E. F., Choat, B., Jansen, S., Phillips, R. J., Shackel, K. A., McElrone, A. J., and Matthews, M. A. 2011. Automated analysis of three-dimensional xylem networks using high-resolution computed tomography. New Phytol. 191:1168-1179.

7. Bruno, G., and Sparapano, L. 2006. Effects of three esca-associated fungi on Vitis vinifera L.: II. Characterization of biomolecules in xylem sap and leaves of healthy and diseased vines. Physiol. Mol. Plant Pathol. 69:195208.

8. Cadle-Davidson, L. 2008. Variation within and between Vitis spp. for foliar resistance to the downy mildew pathogen Plasmopara viticola. Plant Dis. 92:1577-1584.

9. Cadle-Davidson, L., Chicoine, D. R., and Consolie, N. H. 2011. Variation within and among Vitis spp. for foliar resistance to the powdery mildew pathogen Erysiphe necator. Plant Dis. 95:202-211.

10. Carter, M. V. 1991. The status of Eutypa lata as a pathogen. Int. Mycol Inst. Phytopathol. Pap. 32. CAB International, Wallingford, England.

11. Deflorio, G., Franz, E., Fink, S., and Schwarze, F. W. M. R. 2009. Host responses in the xylem of trees after inoculation with six wood-decay fungi differing in invasiveness. Botany-Botanique 87:26-35.

12. Dubos, B. 1987. Mise au point sur les maladies du déperissement dans le vignoble français. Prog. Agric. Vitic. 104:135-140.

13. Eskalen, A., Gubler, W. D., and Khan, A. 2001. Rootstock susceptibility to Phaemoniella chlamydospora and Phaeoacremonium spp. Phytopathol. Mediterr. 40:S433-S438.

14. Feliciano, A. J., Eskalen, A., and Gubler, W. D. 2004. Differential susceptibility of three grapevine cultivars to Phaeoacremonium aleophilum and Phaeomoniella chlamydospora in California. Phytopathol. Mediterr. 43:66-69. 
15. Fritschi, F. B., Lin, H., and Walker, M. A. 2008. Scanning electron microscopy reveals different response pattern of four Vitis genotypes to Xylella fastidiosa infection. Plant Dis. 92:276-286.

16. Gramaje, D., Garcia-Jimenez, J., and Armengol, J. 2010. Field evaluation of grapevine rootstocks inoculated with fungi associated with Petri disease and Esca. Am. J. Enol. Vitic. 61:512-520.

17. Johnson, D. A., and Lunden, J. D. 1987. Incidence and yield impact of Eutypa dieback of grapevine in Washington state USA. Wash. State Univ. Agric. Res. Center Res. Bull. (0993):1-7.

18. Lambert, C., Bisson, J., Waffo-Teguo, P., Papastamoulis, Y., Richard, T., Corio-Costet, M.-F., Merillon, J.-M., and Cluzet, S. 2012. Phenolics and their antifungal role in grapevine wood decay: focus on the Botryosphaeriaceae family. J. Agric. Food Chem. 60:11859-11868.

19. Larignon, P., and Dubos, B. 1997. Fungi associated with esca disease in grapevine. Eur. J. Plant Pathol. 103:147-157.

20. Lecomte, P., Darrieutort, G., Liminana, J. M., Comont, G., Muruamendiaraz, A., Legorburu, F. J., Choueiri, E., Jreijiri, F., El Amil, R., and Fermaud, M. 2012. New insights into Esca of grapevine: the development of foliar symptoms and their association with xylem discoloration. Plant Dis. 96:924-934.

21. Marchi, G. 2001. Susceptibility to esca of various grapevine (Vitis vinifera) cultivars grafted on different rootstocks in a vineyard in the province of Sienna (Italy). Phytopathol. Mediterr. 40:27-36.

22. Mugnai, L., Graniti, A., and Surico, G. 1999. Esca (Black measles) and brown wood-streaking: two old and elusive diseases of grapevines. Plant Dis. 83:404-418.

23. Munkvold, G. P., and Marois, J. J. 1995. Factors associated with variation in susceptibility of grapevine pruning wounds to infection by Eutypa lata. Phytopathology 85:249-256.

24. Nita, M., Ellis, M. A., and Madden, L. V. 2012. Spatial pattern of Phomopsis cane and leaf spot symptoms in commercial vineyards in Ohio. J. Phytopathol. 160:26-36.

25. Nunney, L., Yuan, X., Bromley, R., Hartung, J., Montero-Astua, M., Moreira, L., Ortiz, B., and Stouthamer, R. 2010. Population genomic analysis of a bacterial plant pathogen: novel insight into the origin of Pierce's disease of grapevine in the US. PLoS One 5.

26. Octave, S., Roblin, G., Vachaud, M., and Fleurat-Lessard, P. 2006. Polypeptide metabolites secreted by the fungal pathogen Eutypa lata participate in Vitis vinifera cell structure damage observed in Eutypa dieback. Funct. Plant Biol. 33:297-307.

27. Péros, J. P., and Berger, G. 1994. A rapid method to assess the aggressiveness of Eutypa lata isolates and the susceptibility of grapevine cultivars to Eutypa Dieback. Agronomie 14:515-523.

28. Péros, J. P., Jamaux-Despreaux, I., Berger, G., and Gerba, D. 1999. The potential importance of diversity in Eutypa lata and co-colonising fungi in explaining variation in development of grapevine dieback. Mycol. Res. 103:1385-1390.

29. Ramming, D. W., Gabler, F., Smilanick, J. L., Margosan, D. A., CadleDavidson, M., Barba, P., Mahanil, S., Frenkel, O., Milgroom, M. G., and Cadle-Davidson, L. 2012. Identification of race-specific resistance in North American Vitis spp. limiting Erysiphe necator hyphal growth. Phytopathology 102:83-93.

30. Riaz, S., Tenscher, A. C., Rubin, J., Graziani, R., Pao, S. S., and Walker, M. A. 2008. Fine-scale genetic mapping of two Pierce's disease resistance loci and a major segregation distortion region on chromosome 14 of grape. Theor. Appl. Genet. 117:671-681.

31. Rolshausen, P. E., Baumgartner, K., Travadon, R., Fujiyoshi, P., Mahoney, N., Molyneux, R., and Wilcox, W. 2011. Species identification of the causal agent of Eutypa dieback of grapevine in northeastern U.S. and southeastern Canadian vineyards. Phytopathology 101:S156.

32. Rolshausen, P. E., Greve, L. C., Labavitch, J. M., Mahoney, N. E., Molyneux, R. J., and Gubler, W. D. 2008. Pathogenesis of Eutypa lata in grapevine: identification of virulence factors and biochemical characterization of cordon dieback. Phytopathology 98:222-229.

33. Rolshausen, P. E., Urbez-Torres, J. R., Rooney-Latham, S., Eskalen, A., Smith, R. J., and Gubler, W. D. 2010. Evaluation of pruning wound susceptibility and protection against fungi associated with grapevine trunk diseases. Am. J. Enol. Vitic. 61:113-119.

34. Rooney-Latham, S. 2005. Etiology, epidemiology and pathogen biology of Esca disease of grapevines in California. Ph.D. dissertation, Publ. AAT 3191148, University of California, Davis.

35. Rouxel, M., Mestre, P., Comont, G., Lehman, B. L., Schilder, A., and Delmotte, F. 2012. Phylogenetic and experimental evidence for host-specialized cryptic species in a biotrophic oomycete. New Phytol. 197:251-263.

36. Shain, L. 1979. Dynamic responses of differentiated sapwood to injury and infection. Phytopathology 69:1143-1147.

37. Shigo, A. L. 1984. Compartmentalization: a conceptual framework for understanding how trees grow and defend themselves. Annu. Rev. Phytopathol. 22:189-214.

38. Siebert, J. B. 2001. The economic toll on vineyard. Wines Vines April:50-55

39. Sosnowski, M. R., Lardner, R., Wicks, T. J., and Scott, E. S. 2007. The influence of grapevine cultivar and isolate of Eutypa lata on wood and foliar symptoms. Plant Dis. 91:924-931.

40. Sparapano, L., Giovanni, B., and Graniti, A. 2001. Three-year observation of grapevine cross-inoculated with esca-associated fungi. Phytopathol. Mediterr. 40:S376-S386.

41. Travadon, R., Baumgartner, K., Rolshausen, P. E., Gubler, W. D., Sosnowski, M. R., Lecomte, P., Halleen, F., and Péros, J. P. 2012. Genetic structure of the fungal grapevine pathogen Eutypa lata from four continents. Plant Pathol. 61:85-95.

42. Urbez-Torres, J. R. 2012. The status of Botryosphaeriaceae species infecting grapevines. Phytopathol. Mediterr. 50:S5-S45.

43. Urbez-Torres, J. R., Adams, P., Kamas, J., and Gubler, W. D. 2009. Identification, incidence, and pathogenicity of fungal species associated with grapevine dieback in Texas. Am. J. Enol. Vitic. 60:497-507.

44. Urbez-Torres, J. R., Leavitt, G. M., Guerrero, J. C., Guevara, J., and Gubler, W. D. 2008. Identification and pathogenicity of Lasiodiplodia theobromae and Diplodia seriata, the causal agents of Bot canker disease of grapevines in Mexico. Plant Dis. 92:519-529.

45. Urbez-Torres, J. R., Leavitt, G. M., Voegel, T. M., and Gubler, W. D. 2006. Identification and distribution of Botryosphaeria spp. associated with grapevine cankers in California. Plant Dis. 90:1490-1503.

46. Weber, E. A., Trouillas, F. P., and Gubler, W. D. 2007. Double pruning of grapevines: a cultural practice to reduce infections by Eutypa lata. Am. J. Enol. Vitic. 58:61-66.

47. Zanzotto, A., Gardiman, M., and Lovat, L. 2008. Effect of Phaeomoniella chlamydospora and Phaeoacremonium sp. on in vitro grapevine plants. Sci. Hortic. 116:404-408. 